\title{
Prekmurje Agricultural Terminology in the Dolinsko Region ${ }^{1}$
}

\author{
Minaela Koletnik \\ University of Maribor, Faculty of Arts, Koroška 160, SI-2000 Maribor, \\ mkoletnik@uni-mb.si
}

\begin{abstract}
$\mathrm{V}$ prispevku predstavljamo narečno kmetijsko izrazje za poimenovanje kmečkega orodja, pridelkov, dela na polju in v hlevu v govoru Črenšovcev na Dolinskem v Prekmurju. Gre za raziskavo tematsko zamejenega besedišča, zbranega s terenskimi raziskavami s pomočjo tematskih vprašalnic, slikovnega gradiva in pripovedi informatorjev. Zajeto je staro besedje, ki izginja in ki ga pozna le še najstarejša generacija govorcev, pa tudi sodobno besedje, ki ga je na to področje prinesla sodobna tehnika in ki se ga oprijema mlajša generacija govorcev.

The paper presents the dialectal vocabulary of agricultural items in Črenšovci in the Dolinsko region of Prekmurje, with a focus on agricultural tools, crops, as well as field and stable work. The study is based on a thematically defined vocabulary gathered through fieldwork and with the help of questionnaires, pictures and informants' narratives. It includes archaic vocabulary that is gradually disappearing and is known only to the oldest generation of speakers, as well as the contemporary vocabulary that has been introduced along with the modern technology and is used by the younger generation of speakers.
\end{abstract}

Ključne besede: dialektologija, panonska narečna skupina, prekmursko narečje, poljedelska terminologija

Key words: dialectology, Pannonian dialect group, Prekmurje dialect, agricultural terminology

${ }^{1}$ This article was written as part of the research project J6-2238 Slovenski jezik $v$ stiku evropskega podonavskega in alpskega prostora (The Slovene Language in Contact within the European Danube and Alpine Regions), funded by the Slovenian Research Agency. The project leader is Prof. Marko Jesenšek, Ph.D. 


\section{Introduction}

New developments and changes in all areas of social life are reflected as a matter of course in the rural environment. Lifestyles are changing rapidly, with repercussions for the vocabulary of each dialect - the form and meaning of words have changed, and certain vocabulary strata are increasingly disappearing. It would be a pity to see them disappear completely. This paper presents the vocabulary of agricultural tools, crops, field labour and stable work, which has been gathered through field work and with the help of questionnaires, ${ }^{2}$ pictures and informants' narratives in the Prekmurje village of Črenšovci.

The dialect of Črenšovci, a village first documented in 1322 as Chremsouc (Zelko 1982: 26), is classified according to Slovene dialectology as belonging to the Prekmurje Dolinsko region subdialect. This subdialect is spoken in the south of Prekmurje along the Mura River; up the Ledava River and in Porabje, the Goričko subdialect prevails, and from Cankova across Murska Sobota all the way to Filovci and Kobilje, the Prekmurje Ravensko region subdialect is spoken. Zinka Zorko (1998: 42) differentiates these according to elements of recent Prekmurje dialect development: (1) various acoustic realizations for the long and short $a$; in the Goričko and Ravensko subdialect, both short and unstressed $a$ are rounded, whereas in the Dolinsko subdialect, the influence of the Prleško dialect results in the rounding of the long $a$ into $o: / \stackrel{a}{a}$; both short stressed and unstressed $a$ remain open vowels; (2) development of the final $-l$ into $-o$ in the Goričko and Ravensko subdialect and into $-u$ in the Dolinsko subdialect; and (3) pronunciation of the sonorant $j$ in the Dolinsko and in the east part of the Ravensko subdialect as $j$, in other parts of the region pronounced as $d j, g, k$, or $d \check{z}{ }^{3}$ Older phonetic and morphological developments remain rather uniform.

\section{Dialectal Agricultural Terminology}

Analogous to other fields, dialectal agricultural terminology is dual in nature: on the one hand, it entails specific monosemantic words referring exclusively to objects or activities in the field of agriculture; on the other hand, it is part of general vocabulary, manifesting characteristics of general use and can be semantically or morphologically modified (Cf. Jež 1997: 212).

The dialectal terminology extracted from transcribed texts and complemented by informant interviews is presented in the form of vocabulary entries. ${ }^{4}$ The

\footnotetext{
${ }^{2}$ A Questionnaire for Garden and Orchard by Francka Benedik, A Questionnaire for SLA, a questionnaire developed by Dr. Rada Cossutta on the basis of Q. ALI and ASLEF; the questionnaires were adapted to the Prekmurje economic and cultural profile.

${ }^{3}$ For more information on similarities and differences between the Prekmurje subdialects, see Greenberg (1993: 465-487) and Koletnik (2008: 13-16).

${ }^{4}$ Sample taken from Škofic (2007: 224). For the purpose of this paper, a selection of vocabulary is presented.
} 
structure of a vocabulary entry is as follows: headword in bold font, followed by two vertical separator lines $(\|)$ and the phonetic transcription of the dialect expression in the first (basic) and second dictionary form, i.e., nouns and noun phrases in the nominative and genitive singular (plural for plural nouns); verbs in the infinitive followed by the first-person singular present form; adjectives in the corresponding male, female and neutral forms. The lexical category markers $\mathrm{m}, \mathrm{f}$, and $\mathrm{n}$ denote the grammatical gender of the noun and are also applicable to the subentry headwords with nominal head and adjectival qualifier; perf. and imperf. mark the grammatical aspect of the headword; adj. marks the (relational) adjective that can also occur in pair with a noun head as a subentry of the corresponding lexeme. This is followed by semantic data in italics; if a lexeme is polysemantic, different meanings are categorized by numbers. Illustrative examples follow the colon - a segment from the recorded and transcribed dialectal material that refers to the actual use of a term. The rightwards arrow $\rightarrow$ in adjectival headwords points to the noun headword; in this case, the adjective is the left-hand qualifier in the subentry headphrase. Some entries also contain a left right arrow $\leftrightarrow$ indicating synonyms or lexemes with similar meaning. If the term is borrowed from a foreign language system, the direction of borrowing is traced according to the dictionaries (Bezlaj I-V /1976-2007/, Skok I-III /1971-1973/, Snoj /2003/, Striedter-Temps /1963/) and other reference books marked in square brackets using the leftwards arrow $\leftarrow$.

bel || 'be:ili -a -o adj. white $\rightarrow$ repa

bilje || 'biljä -a n outer layers of the corncob husk leaves: 'Biljä jä uk'ro:uيk vla'ti:i. - A corncob is wrapped in bilje.

bint || 'bint -la m a winnowing machine: 'Nẹgda sä m'la:tilu z 'bintun, g'näs pa m'la:timu s 'kọmbajun. - In the past, one used to thresh with a bint; today, we thresh with a combine. $[\leftarrow \text { G. Wind- }]^{5}$

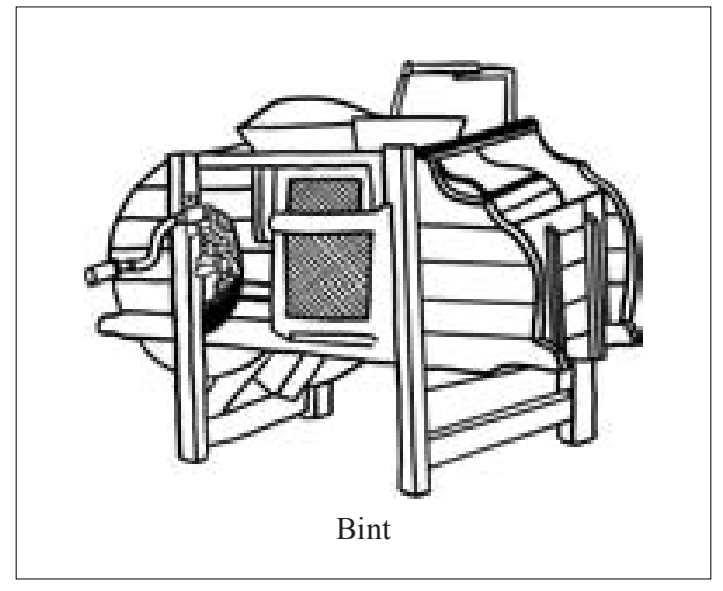

${ }^{5}$ Drawings: Nika Lopert. 
brana || b'ra:na -ä f a tool with iron teeth for loosening the soil, harrow: Z b'ra:nuf v'la:čimu pu 'jivaj. - The brana is pulled around the field.

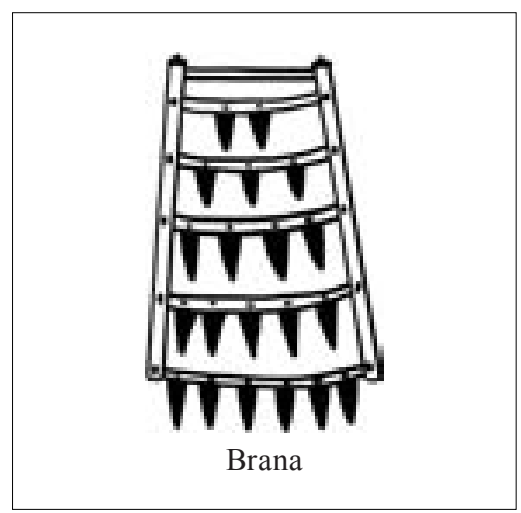

cepe || ci'pi:ẹ 'ce:ịpi f pl. a flail: Ci'pi:ẹ su is t're:i fa'låčkuf: 'rọčnik, 'cẹpič pa 'go:ưžäf. 'Ročnik, 'tü cä'pi:ẹ dróži:îmu. S 'cẹpičun m'la:timu pu gla'va:j s'no:ưpja. 'Go:ư⿱žäf jä 'bi:inla z 'lẹdra. 'Cọj jä 'bü:un z'vi:ẹzani 'lẹdrnio 'rämläk. - A cepe consists of three parts: ročnik, cepič and gožev. The ročnik is used for holding the cepe. With cepič, we thresh the sheaves. A gožev is made of leather and bound with a leather strap.

(1) ročnik || 'rọčnik -a $\mathrm{m}$ the handle of a flail

(2) gožev || 'go:ǔ̃zäf -žvi f the leather binding between two parts of a flail, taplings

(3) cepič || 'cẹpič -a m the part of the flail used for threshing
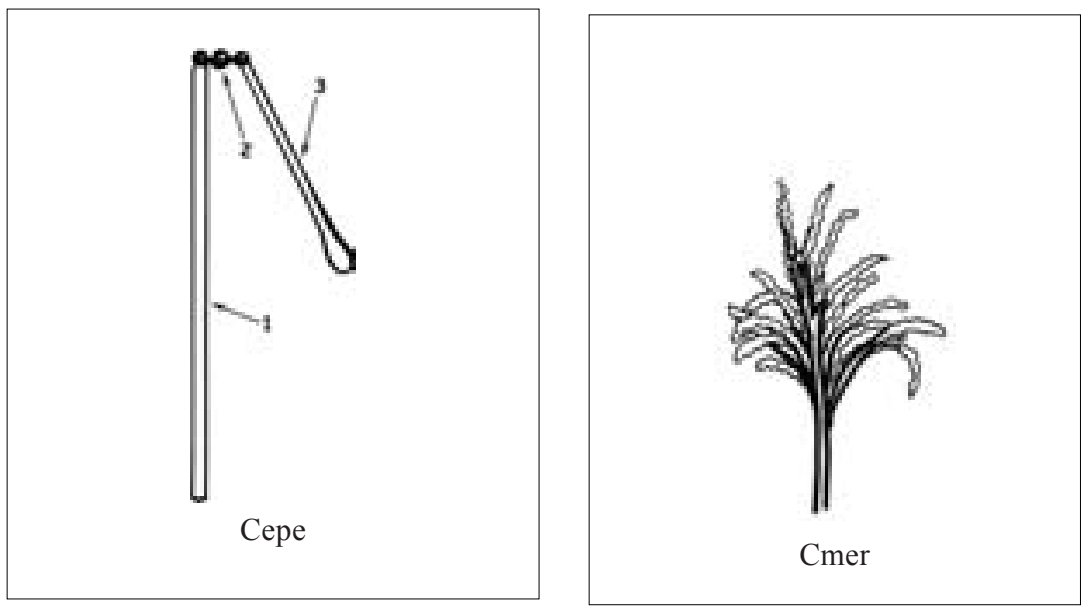

cmer || c'mẹ:ir -a m male inflorescence on the top of the corn (Zea Mays) stalk: 'Kukrca 'ma: 'mäklicu ali c'mẹ:ir. - Corn has metlica or cmer. [ $\leftarrow$ Hun. cimer (Novak 1996: 27)] $\leftrightarrow$ metlica 
cukrnjača || cukr'jåča -ä f white beet: 'Cukär du'bi:inmu s cukrr'jåčă. - Sugar is produced from white beet (cukrnjača).

čeliti || 'čäliti -in imperf. a light threshing of sheaves: 'Då s'nọp m'la:timu, 'tåk kå ž 'jin v'da:rjamu pu 'ädnun s'to:uxcị, p'ra:vimu, 'kå 'čälimu. - When we thresh a sheaf by hitting it against a chair, we say that we čelimo.

gnojiti || gnu'jiti gnu'ji:inn imperf. fertilizing: Š' čä g'näs sä gnu'ji:in z g'nujun. - Even today, manure is used for fertilizing.

grablje || g'råblä g'ra:bäu f pl. rake: Z g'ra:blami sä gr'mådi. 'De:ili g'ra:bäu su grab'liščä, čällü:isst pa 'zọpci. - A grablje is used for raking. It consists of grabljišče, čeljust and zobci.

(1) grabljišče || grab'liščä -a m handle of the rake

(2) čeljust || čällü:isst - $\mathrm{i}$ f the part of the rake where the teeth/tines are attached

(3) zobec || 'zọbäc -pca m a tooth/tine of the rake

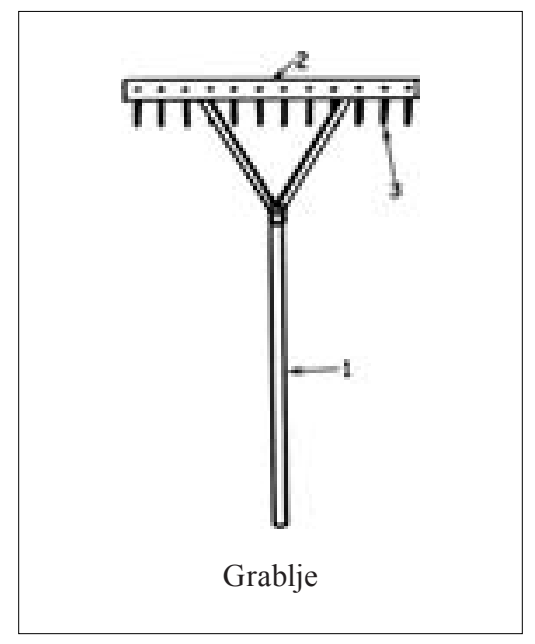

grmaditi || gr'måditi -in imperf. using the rake to heap up material: Z g'ra:blami se grr'mådi. - A rake is used to heap up material (grmadi).

grmalija || gr̊mmålija -ä f a woman using the hay-rake: Grọ'målija gr’mmådị.

grnjač || gr̊nåč -a m a man using the hay-rake: 'Mọškị, 'då gr'mådi, jä gr'nåč. - A man who rakes is called a grnjač.

gumno || 'gümla -ä f threshing floor: Za'to:u smu s'no:upjä sk'la:dali na 'gümlu, kå je bi'lo:u k'ri:ẹdi za ma'ši:in. - Sheaves were gathered on gumno until they were ready for threshing.

hajdina || (x)aj'di:ina -ä f buckwheat: (X)aj'di:ina pa zm'lẹta 'da: 'čornu 'mälu za ž'ga:nikä. -The buckwheat flour is used for preparing žganci (boiled corn mush, grits). [ $\leftarrow$ OG. Heiden] 
ječmen || 'jäčmän jäčlmẹna m barley: 'Jäčmän jä 'na:jpr'li:ẹ z'rẹlia. - Barley is the first to ripen.

kamen || 'kåmän -mna m a stone

kamen za brusiti koso || 'kåmän za b'rü:insitị ku'so:u a long oval stone for sharpening the scythe, a whetstone
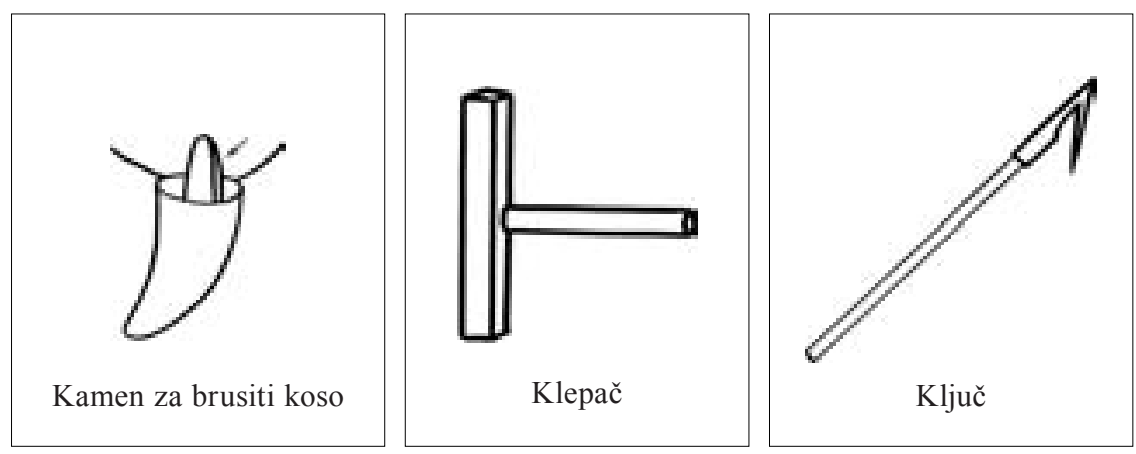

klepač || klä'pa:č -a m a peening hammer: 'Kọsa sä k'läplä s klä'pa:čun. - A scythe is hammered with a peening hammer.

ključ || k'lü:ič -a m a tool for pulling straw from the stack: S'låmu su 'mi:kali s k'lü:ičun. - Straw was pulled from the stack with a ključ.

kola || 'ko:ula 'ko:ul n pl. a wooden (farm) cart: S 'ko:ụlami sä vu'zilu na 'jivä. 'De:ili 'ko:ưl su 'na:rat, 'tån 'bü:ư po'ta:č 'gọ, 'ọplin, 'puza, ru'čicä, 'ru:t, s'fo:ura pa vr'ti:ẹu. Na 'ko:ulaj su šlčä trä'bi:ẹ, p're:idjä pa 'za:djä trä'bi:ẹ. 'Lẹstvicä na 'ko:ulaj pa su räbr'ni:icä. -The kola (the wooden cart) was used as a means of transport to the fields. The parts of the cart are the narad, onto which a wheel (potač) is attached, and the oplen, polza, ročice, rud, svora and vrtel. There are also trebe on the cart, the front and the rear trebe. The small ladders on the cart are called rebrnice.

(1) svora || s'fo:ura -ä f a strong pole connecting the front and back parts of the cart, a perch

(2) narad || 'na:rat -di f a wooden axle of the cart

(3) trebe || trä'bi:ẹ -i:i f pl. a triangular part of the cart, inserted between the undercarriage and oplen and to which the front and rear wheels are attached, frame

prednje trebe || p're:idjü trä'bi:ẹ a triangular part of the cart inserted between the undercarriage and oplen and to which the front wheels are attached, front frame

zadnje trebe || 'za:djä trä'bi:ẹ a triangular part of the cart inserted between the undercarriage and oplen and to which the rear wheels are attached, rear frame

(4) rud || 'ru:t 'ru:da m a pole on the front part of a cart, by which an animal is harnessed to a vehicle; shaft, a thill [ $\longleftarrow$ Hun. rud] 


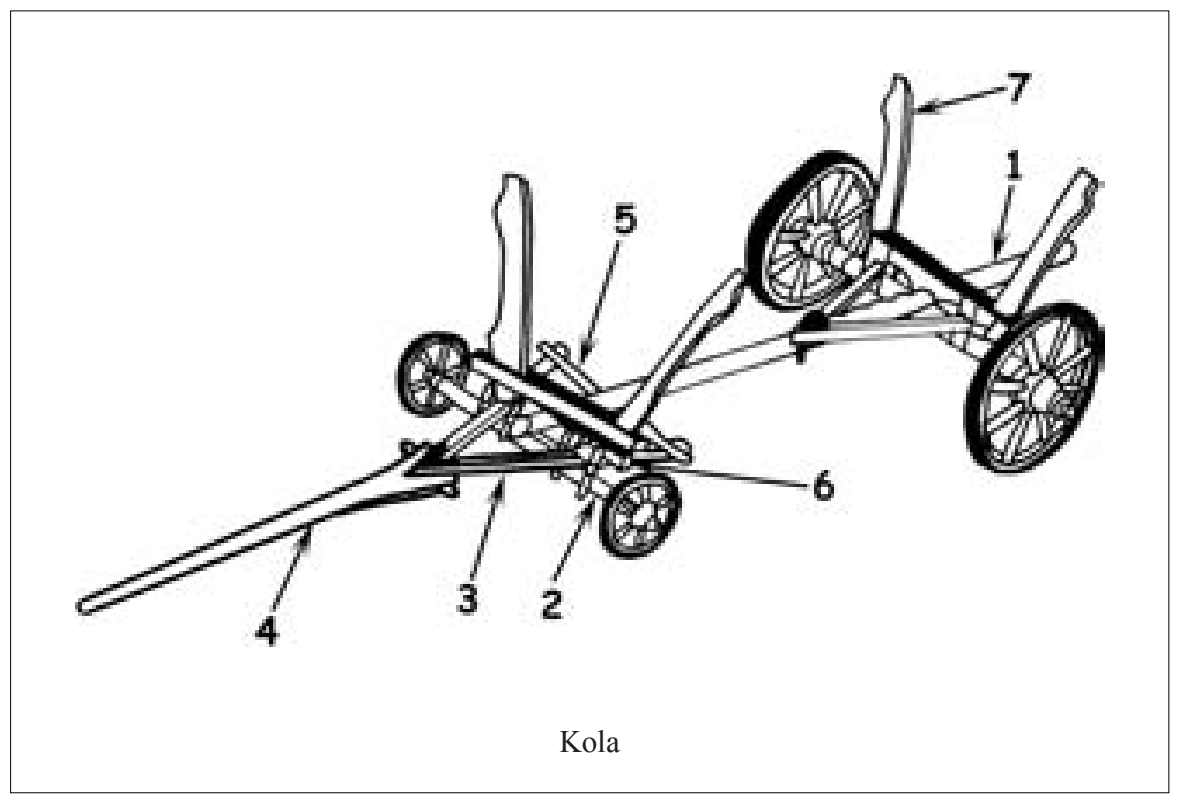

(5) polza || 'puza -ä f part of the front trabje (axle) of the cart (where svora is placed)

(6) oplen || 'ọplin -a m a diagonal pole on the front and rear part of the cart, to which the ročice are affixed $\leftrightarrow$ vrtel

(7) ročica || ru'čica -ä f, pl. ru'čicä ru'či:inc a wooden handle attached to the cart

vrtel || vr'ti:ẹu -la m the front oplen $\leftrightarrow$ oplen

rebrnica || räbróni:inca -ä f, pl. räbro'ni:icä -ø a ladder-like frame attached to the side of the cart

kombajn || 'kọmbaj̃ -a m a combine: 'Kọmbaj̃ pa 'dẹla f'sä z lädnin na 'j̃ivì, ku'si:i pa m'la:ti. - A combine on the field can mow and thresh simultaneously. [ $\leftarrow$ Stand. $\leftarrow$ Eng. combine $]$

kosa || 'kọsa ku'si:ẹ f 1. scythe: 'Nẹgda sä f'sä ku'si:ilu s ku'so:u. 'De:ili ku'si:ẹ su '(x)roät, 'kọsa, ku'siščä, 'müntäun, 'ọsträc, 'pi:ẹta pa 'ri:nčäk. Li'säni 'ta:uِ jä 'ku'siščä, na ku'sišči pa jä 'müntäu. - The kosa used to be the only tool for cutting grass. The parts of a scythe are the hrbet, kosa, kosišče, muntelj, ostrec, peta and rinček. The wooden part is called the kosišče; attached to the kosišče, there is the muntelj. 2. blade of a scythe: Žälli:ẹzni 'ta:u ku'si:ẹ jä 'tüi 'kọsa. - The iron part of the scythe is also called a kosa.

(1) kosišče || ku'siščä -a m snath

(2) hrbet || '(x)rbät -pta m chine

(3) ostrec || 'ọsträc -a m blade 
(4) peta || 'pi:ẹta -ä f heel

(5) rinček || 'ri:nčäk -a m ring

(6) muntelj || 'müntäu -tla m snaith [ $\longleftarrow$ OHG. muntil, south Bav. Mü(n)tel]
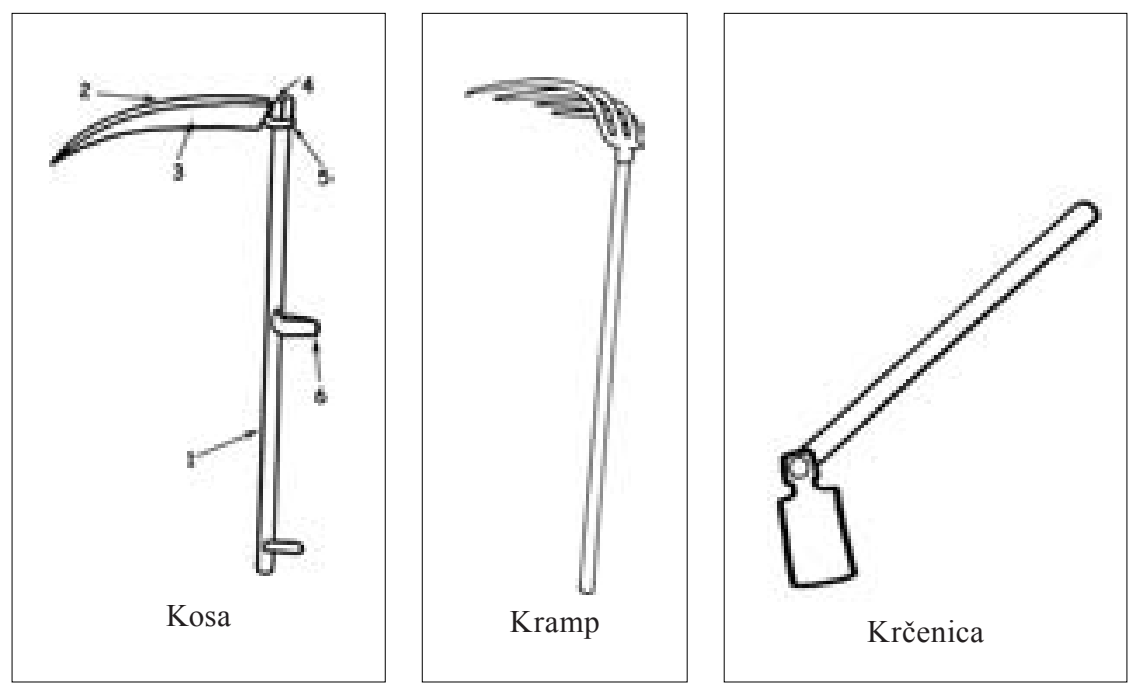

kosilnica || ku'silnica -ä f mowing machine: Ku'si:inu s ku'silnicuf. 'Nẹgda pa su 'mọški f'sä 'pẹški ku'si:inili. -We mow with a mowing machine. Men used to cut grass manually before.

kositi || ku'siti ku'si:in imperf. to cut grass or reap grain: S ku'so:uf ku'si:imu. 'To:u 'dẹlu jä kušä'ji:ẹ. - We cut grass with a scythe. This activity is košenje.

kramp || $\mathrm{k}$ 'råmp -a m a tool with three or four tines for unloading and spreading manure: K'råmp jä za 'dọl ku'pa:ti g'nuj s 'ko:ul na '̃ivi. - A kramp is used for unloading manure on the field. [ $\leftarrow$ MHG. krampe]

krampek || k'råmpäk -a m hoe with a narrow sharpened blade and two tines: K'råmpäk jä za d'ro:ungnu u'ka:pajä. - A krampek is used for hoeing.

krčenica || 'krčänca -ä f a tool with a flat blade set at right angles to the handle and used for digging: 'Krčänca, 'nücali su ju za 'vö 'kọpati pänuv'ji:ẹ. - Krčenica; it was used for pulling out tree stumps.

krumpel || k'rumpäu -pla m, pl. k'rumpli -of potato: K'rumpli zras'ti:eju pud zäm'lo:uf. Su g'la:vna 'ra:na za li'di:i. - The potato grows underground. It is the main food for people. [ $\leftarrow$ Car. G. gruntpirn, grumper, krumpir, Styr. G. grundbir]

krumplovica || k'rumpluvica -ä f the potato plant: K'rumpluvica g'li:ẹda 'vö z zäm'li:ẹ. - The krumplovica grows above ground. 
kukorica || 'kukrca -ä f corn (Zea mays): 'Kukrco šp'rickamu, 'kå 'li:ẹpše ras'ti:ẹ. - Corn is sprayed for better growth. [ $\leftarrow$ Cro. kukùruz $\leftarrow$ Turk. kokoroz]

kukorišče || 'kukřščä -a n dry corn husk: S'låma 'kukrä pa jä 'kukrsščä. - The dry corn husk is called the kukorišče.

lanec || 'lånc -a m a chain for binding the cart wheels: Z 'låncun 'vi:ẹžämu pu'ta:čä. - A lanec is used for binding the cart wheels. [ $\leftarrow$ MHG. lanne]

Iesen || li'säni -a -u adj. the attribute of wood, wooden $\rightarrow$ razsohe

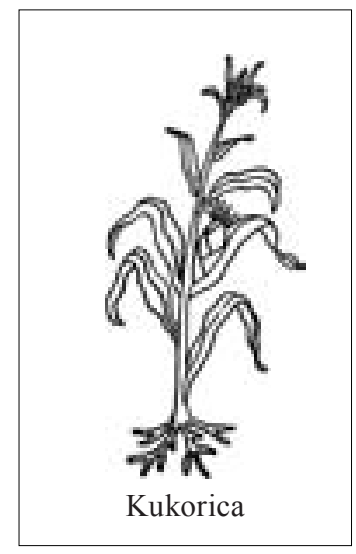

lucerna || lu'cärna -ä f lucerne/alfalfa (Medicago sati$v a)$ : Lu'cärna jä ər'di:ẹča pa 'ma: 'du:ugä c've:itä. - Lucerne is red and has long flowers. [ $\leftarrow$ G. Luzerne $\longleftarrow$ Fr. luzerne $\leftarrow$ Lat. lūcerna ]

lupati || 'lü:ipati -län imperf. to remove husks from the corncob: Vla'ti:i 'lü:iplämu, 'dọl 'trgamo 'bilje. - Husks are peeled; they are pulled off. $\leftrightarrow$ dol trgati

mašin || ma'ši:in -a m a threshing machine: S'no:ụpjä m'la:timu z ma'ši:inun. Sheaves are threshed by a threshing machine. $[\leftarrow$ G. Maschine, Fr. machine $\leftarrow$ Lat. māchina $\leftarrow$ OGr.]

metlica || 'mäklica -ä f male inflorescence on the top of the corn (Zea Mays) stalk: 'Kukraca 'ma: 'mäklicu ali c'mẹ:ir. - Corn has metlica or cmer. $\leftrightarrow$ cmer

mikati || 'mikati 'mi:ičăn imperf. 1. to pull straw from the stack: S'låmu su 'mi:inalị s k'lü:ičun. - Straw was pulled from the stack with a ključ. 2. to pull: Z'́rẹlu 'rẹpu 'mi:ičämu. - Ripe turnips have to be pulled.

mlatec || m'låtäc m'lå(t)ca m a person threshing: Š'täri m'la:ti, jä m'låtäc, či jij jä 'väč, pa su m'låcị. -A person threshing is a mlatec; if there are several, they are called mlatci.

mlatev || m'la:čäf -čvi also -čve f the process of separating grain from the husk or panicle with a flail, a threshing machine, or a combine: 'To:u 'dẹlu, 'kå s ci'pa:mi m'la:timu pu gla'va:j s'no:uيpja, sä zu'vi:ẹ m’la:čäf. - This activity, threshing the sheaves with flails, is called mlačev.

mlatiti || m'la:titi -in imperf. to separate grain from the husk or panicle with a flail, a threshing machine, or a combine: G'näs pa 'sä m'la:tị 'kọmbaj̃, ž'jä pa m'la:ti. - Today, both are done by combine, reaping and threshing (mlatiti).

mrva || 'mrva -ä f hay of low quality: 'Mrva jä s'låba 'krma. - Mrva is bad krma (mown grass).

nakladalka || nakla'da:lka -ä f forage wagon, a hay wain: Nakla'da:lka jä ma'ši:in, š'täri si 'sa:n nak'la:da 'krmu. - A forage wagon is a machine for loading cut grass. 
okopati || u'kọpati u'kọpan perf. hoeing, hilling: 'Då ži k'rumplì 'ma:lu zras'ti:ẹju, 'tä jä tróbe:i u'kopati. - When the potatoes are big enough, you have to hoe them.

orač || u'ra:č -a m ploughman: U'ra:č ur'ji:ẹ. - A ploughman ploughs.

otava || 'o:utava -ä $\mathrm{f}$ (dry) second mowing of grass, aftermath hay: Dri'go:uč ku'si:imu 'o:utavu. - Otava is the secondcut hay.

otika || 'ọtika -ä f a tool for removing soil, weeds, and manure from the plough: 'To:u jä 'ọtika pr p'lügi. - This is the otika in a plough.

oves || 'ọväs 'ọfsa m oats: 'Ọväs pu'la:gaju 'kujun. - Horses are fed oats.

plug || p'lük -ga m a tool or device for tilling the soil, a plough: S p'lügun sä ur'ji:ẹ. 'De:ili p'lüga su 'çřtalu, 'däska, p'lü:ižnu žällẹzu, p'ri:ilič, 'ru:d pa 'pi:ẹta. 'Črtalu jä bi'lo:u za 'rẹzatị b'ra:zde. - A plough is used for ploughing. The

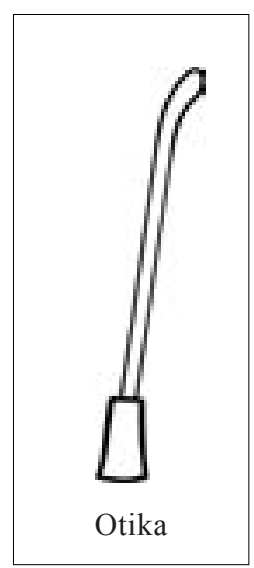
parts of the plough are the črtalo, deska, plužno železo, prilič, rud and the peta. A črtalo is used for drawing the furrows vertically.

(1) prilič $\|$ p'ri:ilič -a m handle [ $\leftarrow$ from priroč $]$

(2) rud || 'ru:t 'ru:da $\mathrm{m}$ a pole on the front part of a plough, by which an animal is harnessed to a vehicle; shaft [ $\leftarrow$ Hun. rud]

(3) črtalo \|| 'črrtalu -a n knife/coulter

(4) železo || žällẹzu -a n iron

plužno železo || p'lü:ižnu žällẹzu ploughshare

(5) deska || 'däska -ä f mouldboard [PS. $\leftarrow$ Rom.]

(6) peta || 'pi:ẹta -ä f chisel

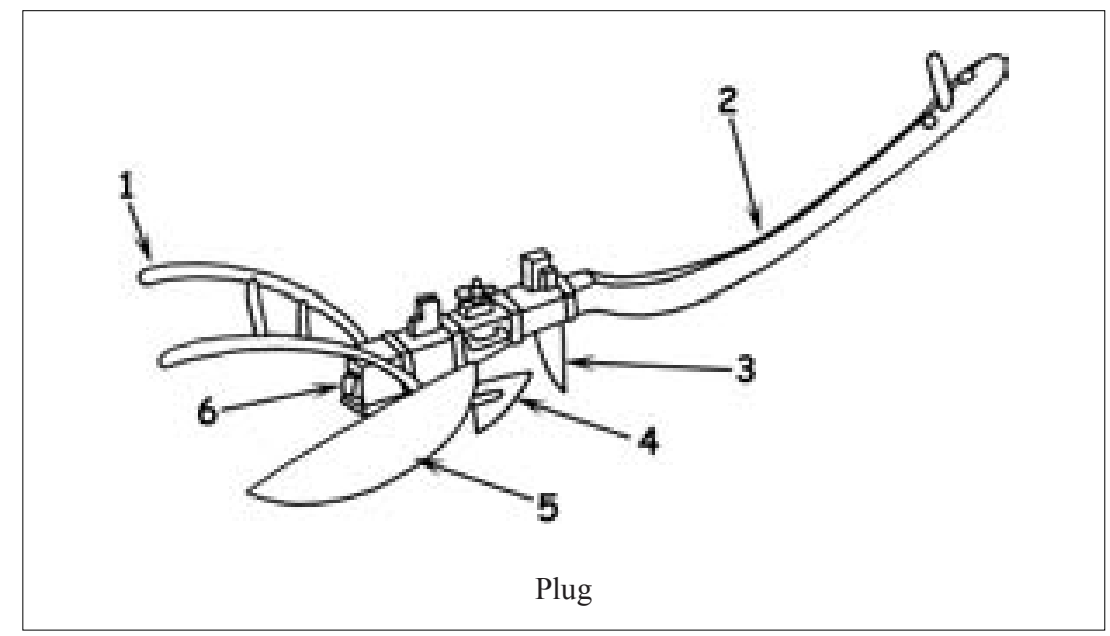


plužen || p'lü:ižän -žna -u adj. referring to the plough $\rightarrow$ železo

potač || pu'ta: ̌́ -a m wheel (of a cart): Na 'ko:ulaj pa su 'tä bi'li:i š ‘̌čä pu'ta:či, š'tirjä. 'De:ili pu'ta:ča su pla'tiščä, 'šija, š'picä, 'pe:istu, š'tẹ:islin pa 'lü:näk. There were also wheels on the cart, four of them. Their parts are called the platišče, šinja, špice, pesto, šteslin and lunek.

(1) platišče || pla'tiščä -a n felloe

(2) šinja || 'šija -ä f the steel rim on a felloe [ $\leftarrow$ G. Schiene $]$

(3) špica || š́pica -ä f spoke

(4) pesto || 'pe:istu -a n hub

(5) šteslin || š'tẹ:jslin -a m the end part of the cart axle (cap) with two inserted nails preventing the wheel from slipping or falling off the axle $[\leftarrow \mathrm{G}$. Stössel]

(6) lunek || 'lü:näk -a m a nail in the axle preventing the wheel from slipping or falling off the axle [ $\leftarrow$ MHG. lun, lune]

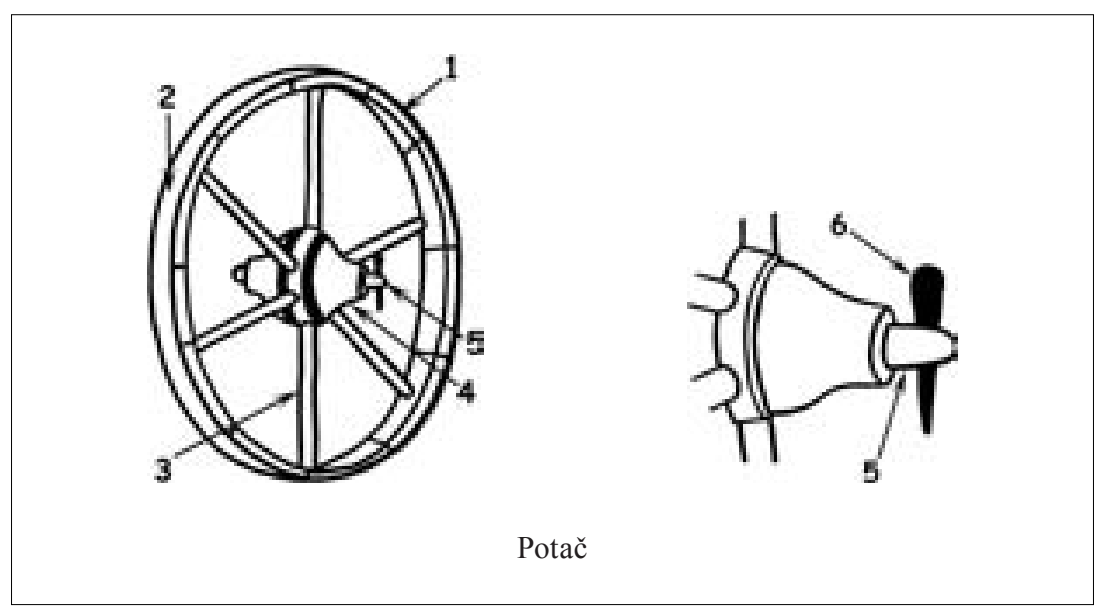

povreslo || puv're:inslu -a n also 'po:unvrisla -ä f a furled wisp of straw for making sheaves: S'nọp sä z'vi:ẹ̌ä s 'po:unvrisluf. - Sheaves are bound with povreslo.

praskač || p'råskač -a m plough for hoeing: 'Kukrocu tro'be:i mäd 'rändami pup'ra:skatị s p'råskačun. - Rows in the cornfield have to be hoed with a praskač.

prednji || p're:indji -a -u adj. the forward part of something $\rightarrow$ trebe

proso || pru'so:u -a n millet: Is pru'sa: du'bi:inu pru'sänu 'kåšu. - We make porridge from boiled millet.

pšenica || pšä'nica -ä f wheat: Pšä'nicu sä'mälämu, 'kå du'bi:inuu 'be:illu 'mälu.

- Wheat can be ground into wheat flour. 
razsohe || 'råsujä -ø f pl. fork

lesene razsohe || li'sänä 'råsujä a long-handled, wooden, three-tine hay fork for lifting or moving hay

železne razsohe $\|$ žä'lẹznä 'råsujä a long-handled, iron, four-tine fork for moving manure
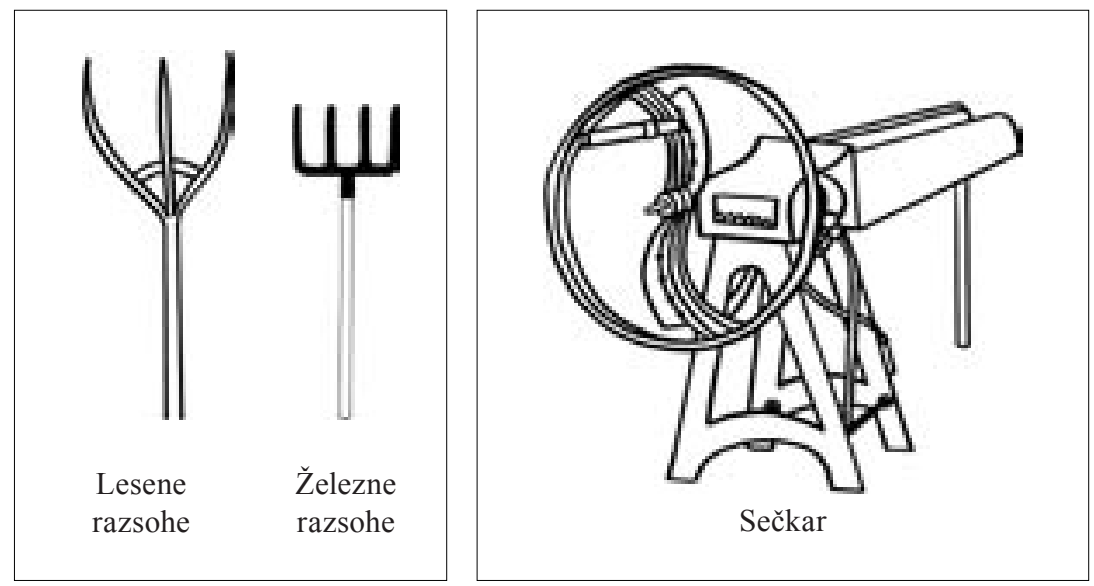

razstava || 'ra:stava -ä f a cluster of (usually ten) freshly stacked sheaves in a field: Pru'sänu s'no:upjä smu pus'ta:vili v 'ra:stavu. - The sheaves of millet were set into razstava.

renda || 'rända -ä f a row/line: 'Kukrco tr'be:i mäd 'rändami pup'ra:skati s p'råskačun. - Rows in the cornfield have to be hoed with praskač. [ $\leftarrow$ Hun. rend $\leftarrow$ s. red]

repa || 'rẹpa -ä f turnip

bela repa || 'be:ila 'rẹpa white turnip (Brassica rapa): 'Be:ilu 'rẹpu pa pu'la:gamu 'ma:rxi. - White turnip is fed to the cattle.

rezač || rilza:č -a m strawcutter - a device for manual cutting of grass or straw: 'Rọcnu su s'låmu 'rẹzali z ri'za:čun. - Straw was manually cut with rezač.

rips || 'rips -a m rapeseed: 'Rips pa 'žu:untu cvä'ti:ẹ. 'Ra:da ga lje:i 'ma:rxa. Rapeseed blossoms are yellow. Cattle like to eat it. [ $\leftarrow$ G. Raps]

sečkar || 'sẹčkar -a m a larger device with a wheel for cutting (maize) straw: S'låmu, 'kukrsščä pa su 'rẹzali s ' 'sẹčkarun. 'To:u jä ma'ši:inn z 'välkin pu'ta:čun. - Straw and maize straw were cut with a sečkar. This is an implement with a large wheel.

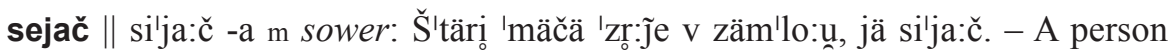
scattering the seeds over the soil is sejač. 
sejalnica || 'sẹjanca -ä f a round or oval basket for seeds used for sowing: Is 'sẹjancä 'sẹjamu. - We sow from a sejalnica.

sejati || 'sẹjati -an imperf. to sow: 'Då 'mäčämu 'zr:jä v zäm'lo:u, 'tä p'ra:vimu, 'kå 'sẹjamu. - When we scatter seeds over the soil, we say that we are sowing.

silje || 'siljä -a n rye: 'Ži:ẹtva jä, 'då sä ku'si:i 'siljä. - At the time of harvest, silje is cut. $\leftrightarrow$ žito

snop || s'nọp -a m a larger wisp of reaped grain or straw, a sheaf: 'Mọški su ku'si:inili, 'Žänskä pa su 'dẹlalä s'nọpä. -The men used to cut grass and the women made sheaves.

srp || 'sr:p -a also sr'pa: m a tool with a wooden handle and curved blade for cutting crops, a sickle: S 'sr:pun t'ra:vu bä'ri:ẹmu, 'kåj 'se:ikamu, 'nẹgda pa sä 'tüi 'žälu 'sra:pun. - A sickle is used for clearing grass or cutting; in the past, it was used for harvesting.
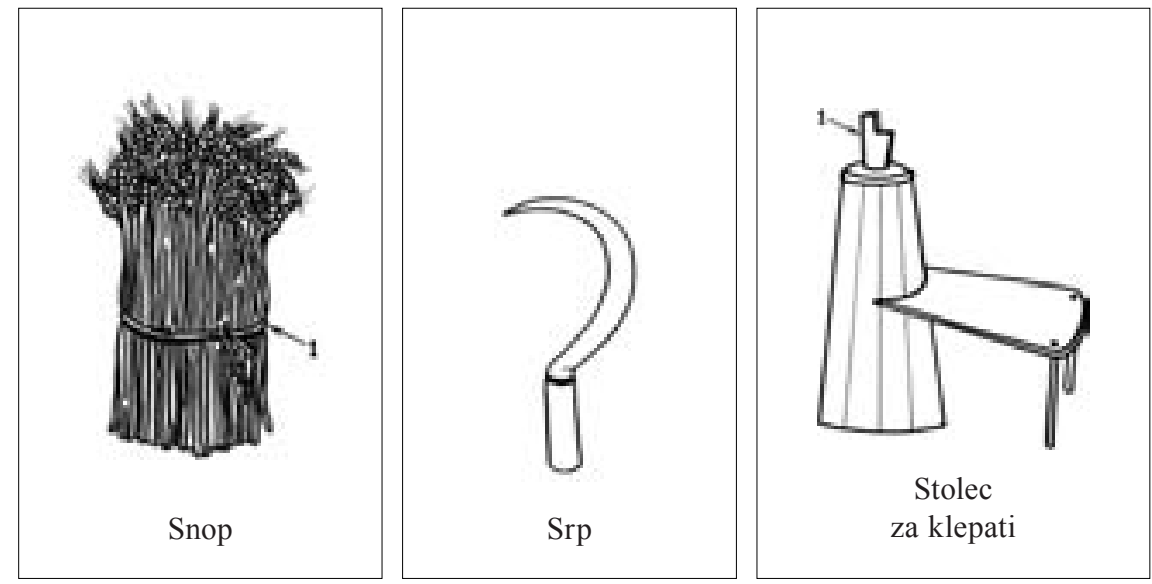

stolec || s'tọläc s'tọuca m seat, chair

stolec za klepati || s'tọläc za klä'påti a sharpening-anvil: 'Gọr na s'tọucio za klä'påti pa jä 'båpka. -The babka is part of the sharpening-anvil.

(1) babka || 'båpka -ä f the upper part of the sharpening-anvil: 'Båpka jä žä'lẹzni̊ fa'låčäk na s'tọucio za klä'påti. - A babka is the small iron part of the sharpening-anvil.

strnišče || stríniščä -a n a stubble of short stalks in the field after harvesting: 'Tån, 'gẹ jä bi'lo:u pu'žätu 'žitu, jä str'niščä. - Where žito has been cut, stubble remains in the field.

šker || š'ki:ẹr -i f tool or implement: Lu'pa:ta pa k'råmp pa k'råmpäk f'küpär, 'tọmi 'mi:i p'ra:vimu š'ki:ẹr. - The shovel and mattock and krampek altogether are called šker. [ $\leftarrow$ OHG. giskirri, MHG. geschirre] 
tikev || 'tikäf -kvị f pumpkin: 'Na:jpṛ'li:ẹ su 'tikvị zä'li:ẹnä, 'tä sä pa pu'måli 'zọiiju pa gra'čüvläju 'žu:ưtä. 'Tikvị zras'ti:ẹju lja:ku 'däbälä. - Pumpkins are green at first; when they ripen, they get yellow. They can become very big.

traktor $\|$ tråktur -a m a motor vehicle used to pull heavy loads, especially farm implements, a tractor: G'näs'di:ẹn f'sä ur'ji:ẹmu s t'råkturun. - Today, a tractor is used for soil cultivation. [ $\leftarrow$ G. Traktor $\leftarrow$ Lat. tractor]

trgati || 'trgati -an imperf. to pull/tear something off

trgati dol || 'dọl 'trgati to remove husks from the corncob $\leftrightarrow$ lupati

vlačiti || v'la:čiti -in loosening the soil with a harrow (brana): Z b'ra:nuf v'la:čimu pu 'jivaj. - The brana is pulled (vlačiti) around the field.

vlat || v'la:t vla'ti:i f 1. corncob with husk leaves: 'Biljä je uk'ro:uk vla'ti:i. A corncob is wrapped in bilje. 2. the upper part of a plant with grain, for example in oats or millet: Udz'gọra 'ma: s'nọp vlatuv'ji:ẹ. - Sheaves have vlati on the top.

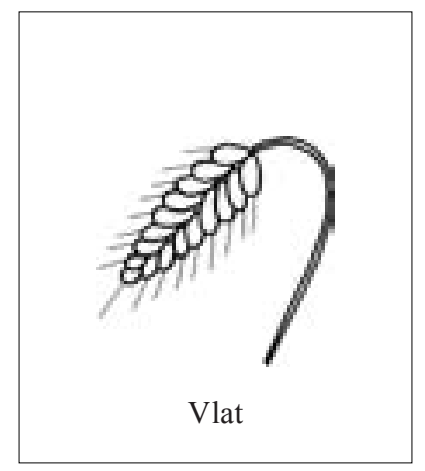

vratnica || vrat'ni:ica -ä f a patch of grass at the edge of a field, where the plough is turned during ploughing: Na 'kunci 'jivä pa su vrat'ni:incä. - At the edge of a field, there are vratnice.

zadnji || 'za:dj̃i -a -u adj. the rear part of something $\rightarrow$ trebe

žanjec || ži'jüc -a m harvester: 'Žitu je pu'ko:usu ži jääc s ku'so:uরf. - A žanjec cuts žito with a scythe.

železen || žällẹzän -zna -u adj. made of iron $\rightarrow$ razsohe

žetev || 'ži:ẹtva -tvä f harvest: 'Ži:ẹtva jä, 'då sä ku'si:i 'siljä. - At the time of the harvest, the silje is cut.

žito || 'žitu -a a cultivated plant yielding starchy grain suitable for food (cereal), or its grains; rye: 'Žitu pa zras'ti:ẹ lja:ku 'visku, zm'lẹtu pa 'da: 'čornu 'mälu. 'Žitu je 'əršs. - Žito can grow very high; it can be ground into whole-grain flour. Žito means rye. $\leftrightarrow$ silje 


\section{Vocabulary and its Origin}

The compiled material in Črenšovci shows that the dialectal agricultural terminology is still well preserved. The basic (old) dialectal agricultural terminology is Slavic; loanwords are mostly of Germanic origin. The oldest German loanwords in the Prekmurje dialect, e.g., muntelj and šker, can be traced back to Old High German. Both these words are used only in the dialect. Loanwords from Middle High German and later, borrowed predominantly from Bavarian German, are marked by Standard Slovene as neutral - kramp, dialectal - lunek, rips or eastern dialectal - (x)ajdina; one word is time-bound-lanec; the words krumpel, šinja and šteslin can be found only in the dialect. A large number of loanwords of Romance origin entered the Pannonian vocabulary via the German language, e.g., lucerna, traktor, mašin - the first two words qualify as neutral and the third one as colloquial. From Hungarian, the words rud and cmer are borrowed. This indicates that the influence of Hungarian (being of non-Indo-European origin) was less significant for the Prekmurje dialect than the influence of German. ${ }^{6}$

One loanword entered the dialect from English via Standard Slovene - kombajn, another was borrowed from the Turkish language via Croatian - kukorica.

\section{Conclusion}

The variety of changes in Slovene society and language is reflected in the Prekmurje Dolinsko region vocabulary in the field of agriculture. For centuries, this vocabulary has been developing at the crossroads of the three largest European language areas; consequently, the range of Romance, Germanic and general Slavic elements based on the native Proto-Slavic vocabulary is clearly reflected in the Pannonian dialect. We can observe that Prekmurje dialect expressions in the field of agriculture and other areas related to rural life still constitute a rich native Slavic substratum, as loanwords entail merely $20 \%$ of the vocabulary. Owing to the constantly changing situation (technical innovation, exchange of tools, new farming methods), however, the ancient and even general Slavic terminology related to farming is gradually disappearing from use in the middle generation of speakers and is practically unknown to the younger generation. Recent vocabulary established in accordance with Slovene word-formation rules often adopts the already existing loanwords (e.g., kombajn).

By creating an inventory of the existent and gradually disappearing terminology, we seek to prevent it from falling into oblivion and to stimulate a comparison between terminological vocabulary material of various Slovene dialects. This would allow for a demarcation of the individual lexeme areas

\footnotetext{
${ }^{6}$ Agricultural vocabulary of Slavic origin has been borrowed by Hungarian as well, a phenomenon which can be observed in the following examples: Hun. kukorica 'koruza' (corn/maize), rend 'red, vrsta (sena)' (row, line of hay), and ugorka 'kumara' (pickle).
} 
and their semantic range, as well as contributing to the realization of the idea of creating discrete Slovene dialectal terminology dictionaries.

\section{LANGUAGE ABBREVIATIONS}

Eng. - English, Bav. - Bavarian, Fr. - French, OGr. - Old Greek, Cro. - Croatian, Stand. - Standard, Car. - Carinthian, Lat. - Latin, Hun. - Hungarian, G. - German, PS. - Proto-Slavic, S. - Slavic, Rom. - Romance, Slo. - Slovene, MHG. - Middle High German, O. - Old, OHG. - Old High German, Styr. - Styrian, Turk. - Turkish.

\section{SOURCES}

France BEZLAJ, 1976-2007: Etimološki slovar slovenskega jezika. Ljubljana: Mladinska knjiga.

Rada COSSUTTA, 2002: Poljedelsko in vinogradniško izrazje v slovenski Istri. Koper: Zgodovinsko društvo za južno Primorsko and Znanstveno-raziskovalno središče RS.

Michael CLYNE, 1972: Perspectives on language contact. Melbourne: The Hawthorn Press.

Marc GREENBERG, 1993: Glasoslovni opis treh prekmurskih govorov. Slavistična revija 41/4, 465-487.

Marija JEŽ, 1997: Iz tkalskega izrazja na Pohorju. Slovensko naravoslovno-tehnično izrazje. Ed. Marjeta Humar. Ljubljana: ZRC SAZU. 209-216.

Janko JURANČIČ: 1966: O leksiki v panonskih govorih. Panonski zbornik. Ed. Božidar Borko, Franc Zadravec. Murska Sobota: Pomurska založba. 31-41.

Mihaela KOLETNIK, 2008: Panonsko lončarsko in kmetijsko izrazje ter druge dialektološke razprave. Maribor: Mednarodna založba Oddelka za slovanske jezike in književnosti, Filozofska fakulteta. (Mednarodna knjižna zbirka Zora, 60).

Franc and Vilko NOVAK, 1996: Slovar beltinskega prekmurskega govora. Murska Sobota: Pomurska založba.

Martina OROŽEN, 2003: Odvisnost narečnega besedišča in načina upovedovanja (izražanja) od spreminjajočega se načina življenja. In: Martina Orožen: Razvoj slovenske jezikoslovne misli. Maribor: Slavistično društvo Maribor. (Zora 26). 310-318.

Petar SKOK, 1971-1973: Etimologijski rječnik hrvatskoga ili srpskoga jezika 1-3. Zagreb: JAZU.

Marko SNOJ, 1997, 2003: Slovenski etimološki slovar. Ljubljana: Mladinska knjiga. - -, 2006: O tujkah in izposojenkah v slovenskem jeziku. Slavistična revija 54. 343-349. 
Hildegard STRIEDTER TEMPS, 1963: Deutsche Lehnwörter im Slowenischen. Berlin: Osteuropa-Institut Berlin, Berlin-Dahlem.

Matej ŠEKLI, 2005: Odraz medjezikovnih stikov v poimenovanjih za vaške poklice in dejavnosti v nadiškem narečju. Večkulturnost $v$ slovenskem jeziku, literaturi in kulturi. Ed. Marko Stabej. Ljubljana: Center za slovenščino kot drugi/tuji jezik pri Oddelku za slovenistiko Filozofske fakultete. 176-181.

Jožica ŠKOFIC, 2007: Terminologija izginjajoče/izginule obrti - sekirarstvo v Kamni Gorici na Gorenjskem. Besedje slovenskega jezika. Ed. Marko Jesenšek. (Zora 50). Maribor: Slavistično društvo Maribor. 214-234.

Peter WEISS, 2006: Besedje na kolesu v (slovenskem) narečnem slovarju z etimologijami. Diahronija in sinhronija v dialektoloških raziskavah. Eds. Mihaela Koletnik, Vera Smole. (Zora 41). Maribor: Slavistično društvo Maribor. 328-335.

Ivan ZELKO, 1982: Historoična topografija Slovenije. Prekmurje do leta 1500. Murska Sobota: Pomurska založba.

Zinka ZORKO, 1998: Narečne prvine v Ivanocyjevem Kalendarju Najszvetejsega szrca Jezusovega (1904-1906). Slovensko-madžarski jezikovni in književni stiki od Košiča do danes. Ed. István Nyomárkay in Stjepan Lukač. Budimpešta: Košičev sklad. 39-59.

Andreja ŽELE, 1996: Voz na Pivškem. Traditiones 25. Ljubljana: SAZU. 337-343.

\section{PREKMURSKA DOLINSKA POLJEDELSKA TERMINOLOGIJA}

Prispevek obravnava prekmursko dolinsko poimenovalno besedje s področja poljedelske dejavnosti. Gre za strokovno izrazje, ki zaradi spreminjajočega se načina življenja izginja iz aktivnega besednega zaklada govorcev. Prekmurski izrazi za poljedelstvo in vse, kar je povezano s kmečkim življenjem, sicer še tvorijo bogat izvirnoslovanski substrat, vendar pa stara slovanska terminologija pri srednji generaciji govorcev hitro tone v pozabo, mlajša generacija pa je sploh ne pozna več. Stoletja ustaljeno kmetijsko orodje so zamenjali različni stroji in pripomočki, skupaj z njimi pa se prevzemajo tudi poimenovanja zanje.

Besedje tujega izvora $\mathrm{v}$ narečni poljedelski terminologiji je zlasti germansko in romansko, kar kaže na to, da je bil stik z neindoevropskim madžarskim jezikom za prekmurščino manj usoden kot nemščina, prek katere so bili v panonsko leksiko največkrat sprejeti tudi romanizmi, čeprav je bilo Prekmurje s Porabjem od 11. stoletja sestavni del ogrskega kraljestva in odtrgano od drugih slovanskih pokrajin. 